\title{
DECOMPOSITION METHOD FOR FORECASTING THE NUMBER OF PARTICIPANTS OF NEW FAMILY PLANNING IN SURABAYA
}

\author{
Dinana Izzatul Ulya ${ }^{1}$, Mahmudah ${ }^{2}$ \\ ${ }^{1,2}$ Department of Biostatistics and Population, Faculty of Public Health, Universitas Airlangga, 60115 Surabaya, East Java, \\ Indonesia \\ Corresponding Author: Dinana Izzatul Ulya \\ E-mail: nana.ulya@gmail.com
}

\begin{abstract}
Indonesia is a country that has a large population and Family Planning Program was initially designed to control the population. This study aimed to forecast new Family Planning Program participants in the city of Surabaya in 2019 using the decomposition method. This study used secondary data, which is the number of participants for new Family Planning Program in January 2014 to December 2018 (60 plots of data) obtained from the PCWECP Surabaya. The researcher chose decomposition method in this study because decomposition is a one-time series method that has rarely been applied in a research. Based on the results of the study, the number of participants for new Family Planning Program from January to December 2019 was 2,776; 2,663; 2,504; 2,340; 2,440; 1,912; 2,$034 ; 2,291 ; 2,223 ; 2,123 ; 2,123 ; 2,130$ and 2,560 participants. The error value generated by this study is MAPE of 9, MAD of 365, MSD 197,738, and MSE of 2.1675. The best error value is the one that has the smallest value, so the MSE is the best model.
\end{abstract}

Keywords: forecasting, family planning, the decomposition method

\begin{abstract}
ABSTRAK
Indonesia merupakan salah satu negara yang memiliki jumlah penduduk cukup banyak. Program Keluarga Berencana (KB) dibentuk untuk mengendalikan pertumbuhan penduduk. Penelitian ini bertujuan untuk melakukan peramalan pada peserta KB baru di Kota Surabaya tahun 2019 dengan metode dekomposisi. Penelitian ini menggunakan data sekunder yaitu jumlah peserta KB baru pada Januari 2014-Desember 2018 (60 plot data) yang didapatkan dari Dinas Pengendalian Penduduk, Pemberdayaan Perempuan, dan Perlindungan Anak (DP5A) Kota Surabaya. Pemilihan metode dekomposisi dalam penelitian ini karena dekomposisi merupakan salah satu metode time series yang sudah jarang digunakan dalam suatu penelitian. Berdasarkan hasil penelitian, peramalan jumlah peserta KB baru dari bulan Januari-Desember 2019 yaitu 2.776; 2.663; 2.504; 2.340; 2.440; 1.912; 2.034; 2.291; $2.223 ; 2.123 ; 2.130$ dan 2.560 peserta. Nilai error yang dihasilkan penelitian ini yaitu MAPE sebesar 9, MAD sebesar 365, MSD 197.738, dan MSE sebesar 2,1675. Nilai error yang terbaik adalah yang memiliki nilai terkecil, sehingga MSE merupakan model terbaik.
\end{abstract}

Kata kunci: peramalan, keluarga berencana, metode dekomposisi

Received: July 23, 2019

Accepted: August 27, 2019

\section{INTRODUCTION}

Forecasting is a method for predicting an event in the next few years. In forecasting, accurate historical data is needed in order to produce good forecasting results in the future. One of the goals of forecasting is serving as a tool to plan effective and efficient programs (Hyndman and Athanasopoulos, 2018). Program planning is needed to improve something or targets to be achieved.

The forecasting method has two methods, subjective and objective. One of the objective forecasting methods is the time series analysis method. The data used in this analysis are data from past or historical data. Time series is used to predict the condition of data that has a pattern so that the pattern can continue. The time series model is the result of continuous observations on variables that have been arranged according to the same time interval, such as every hour, every day, every week, and every year (Kasanah, 2016). Time series has several methods, the method that is often used is the Autoregressive Integrated Moving Average (ARIMA) and the method that has been used for a long time is the decomposition method. 
Decomposition produces the same accuracy value as the ARIMA method and this method provides additional information related to trends that might not be present in ARIMA.

This research uses the decomposition method, this method is the oldest forecasting approach (Makridakis, Wheelwright, and McGee, 1995). Some economists can recognize and control the business cycle by using the decomposition method. One of the steps in the approach to periodic analysis is to identify components that affect each periodic data value. The purpose of this method is to estimate the seasonal effects used to create and present seasonally adjusted data.

The decomposition method separates data into three parts of an initial data pattern that better illustrates the economic and business data series. Three parts are separated which are cycle, seasonality, and trend (tendency) (Makridakis, Wheelwright and McGee, 1995). The tendency factor describes the pattern of data in the long run that tends to be unchanged, increased, or even decreased. Cycle factors indicate an increase or decrease in certain economies or industrial fields. Seasonal factors are related to the instability of periods, usually caused by temperature, rainfall, and months in a year (Makridakis, Wheelwright, and McGee, 1995).

Forecasting data produces results that are not necessarily accurate, there will be differences between forecasting data with actual data (Harjono and Kuntoro, 2017). The accuracy of a forecast is seen from the difference in distance from forecasting data and actual data. The right method to see the accuracy of forecasting one of them is Mean Square Error (MSE). MSE values are getting smaller or fewer then the results of forecasting become very accurate.

Other methods used are MSD and Mean Absolute Percentage Error (MAPE). MAPE is often used because this method is better than MSD. MAPE value is better because it shows the error value from the results of actual data forecasting in a period. The accuracy of forecasting is harmonized with time series data and then gives results in percent.

Indonesia is one of several other countries that have a large number of populations. Indonesia's population in 2010 according to Population Census data was 237,565,706 inhabitants, while in 2015 it reached $258,200,000$ inhabitants. According to the data population census, in 2010 the population in East Java reached 37,565,706 inhabitants and in 2015 as many as $38,847,561$ inhabitants. Indonesia's population, more specifically in East Java, is increasing through years, therefore a program to limit birth rates called the Family Planning Program is designed.

Based on the Law of Indonesian Republic Number 52 Year 2009 Concerning Population Development and Family Development, the Family Planning Program is an effort to regulate childbirth rates and regulate pregnancy intervals, by providing additional information and providing assistance following the reproductive rights of acceptors to produce quality families. Family Planning Program is not only an effort to control births but also to build awareness among families to have attention and support related to socio-cultural, economic, educational, and health issues so that family life will be prosperous ( National Board of Population and Family Planning, 2018). Participants in the new Family Planning Program are acceptor or Fertile Age Couple (FAC) who have tried to use contraception for the first time or FAC who use contraception again after the acceptor has given birth.

Various types of contraception that are often used by the public are called the LongTerm Contraception Method (LTCM) and NonLTCM. LTCM contraceptives include IntraUterine Device (IUD), implants, tubectomy, and vasectomy, while for non-LTCM such as injections, pills, and condoms. This study predicts the number of new birth control participants with all kinds of contraception used.

New family planning participants in East Java are increasing every year. In 2015, coverage of new family planning participants reached $10.8 \%$ of all provinces in Indonesia, whereas, in 2016, the number of family planning participants only reached 903,595 acceptors. Based on the results of the Surabaya Central Bureau of Statistics, in 2012-2014 the number of new acceptors participating in family planning has increased and decreased. Meanwhile, based on data from the Department of Population Control, Women's Empowerment, and Child Protection (PCWECP) of Surabaya, from January 2014 to December 2018 when viewed from annual data, it decreased, whereas when viewed from monthly data, the data tended to be unstable or increased and increased decrease. 
The purpose of this study is to apply the decomposition method to determine the forecasting results of the number of new Family Planning participants in 2019. Forecasting of new Family Planning participants needs to be done to plan programs related to family planning programs in the future.

Forecasting uses the decomposition method to predict the number of new Family Planning participants but not yet knowing the exact forecast results, so this study can be used to determine the forecasting patterns and models. The data used are new Family Planning participant data recorded every month in PCWECP Surabaya.

\section{METHODS}

This research is non-reactive. Data were collected at the Surabaya PCWECP by taking secondary data in the form of the number of new Family Planning Program participants from January 2014 to December 2018. The amount of data used was by the minimum limit for forecasting or forecasting, which was 60 points.

The dependent variable of this study is the number of new Family Planning participants and the independent variable is time (data per month). The purpose of applying the decomposition method is to break the data into 4 parts, these 4 components will be used in the forecasting process.

The application of the decomposition method begins by breaking down the data according to trend, seasonal, cycle, and irregular components. The next process is forecasting and then testing the suitability of the model by finding the smallest error value.

\section{RESULT}

\section{Overview of the Number of New Family} Planning Program Participants in the City

Based on table 1, from 31 sub-districts in Surabaya, data on the number of new Family Planning Program participants in the city of Surabaya from 2014 to 2018 can be seen that each month and year shows an increase and decrease in the number of new family planning participants. The highest number of family planning participants was in January 2014 with 6,383 people, while the smallest number of family planning program participants was in December 2018 with 2,375 people. Table 1 shows the number of new birth control participants from all types of contraception used.

Table 1. Number of New Family Planning Program Participants from 2014 to 2018

\begin{tabular}{lrrrrr}
\hline \multirow{2}{*}{ Month } & \multicolumn{5}{c}{ Year } \\
\cline { 2 - 6 } & $\mathbf{2 0 1 4}$ & $\mathbf{2 0 1 5}$ & $\mathbf{2 0 1 6}$ & $\mathbf{2 0 1 7}$ & $\mathbf{2 0 1 8}$ \\
\hline Jan & 6,383 & 5,472 & 3,848 & 3,929 & 3,674 \\
Feb. & 5,853 & 5,526 & 4,203 & 3,786 & 2,978 \\
Mar. & 6,054 & 4,953 & 3,702 & 3,601 & 3,517 \\
Apr & 5,576 & 4,526 & 3,293 & 3,875 & 3,024 \\
May & 4,664 & 4,257 & 4,080 & 3,624 & 3,221 \\
June & 4,609 & 3,348 & 2,987 & 3,762 & 2,574 \\
July & 4,146 & 3,761 & 3,489 & 3,211 & 3,067 \\
Aug. & 5,489 & 4,220 & 3,849 & 3,527 & 2,862 \\
Sept. & 5,605 & 4044 & 3,908 & 3,184 & 3,066 \\
Oct & 5,198 & 3,990 & 3,088 & 3,377 & 3,281 \\
Nov & 5,387 & 3,947 & 3,902 & 3,138 & 3,121 \\
Dec. & 7,273 & 5945 & 3,915 & 3,444 & 2,375 \\
\hline
\end{tabular}

Based on Figure 1, time series data plot decreased from 2014 to 2018. The average number of new family planning participants increased in August and December, but in August and December 2018 the number of new family planning participants decreased significantly. Meanwhile, the average new family planning program participant always decreases in June, but in June 2017 there has been an increase in the number of participants.

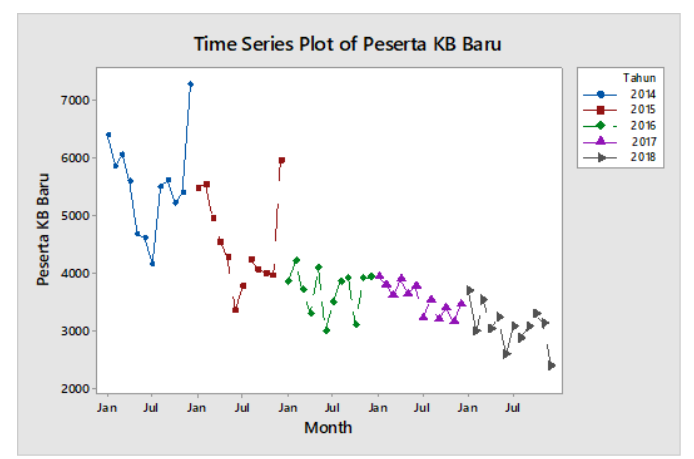

Figure 1. Data Plot Number of New Family Planning Program Participants in Surabaya from 2014 to 2018

\section{Trend Component Analysis}

Based on the results of data analysis, the monthly data trend equation shows the number of new Family Planning participants: $\mathrm{Yt}=$ 
$5538-48.14 \mathrm{X}_{\mathrm{t}}$, and the results of trend analysis are shown in Figure 2.

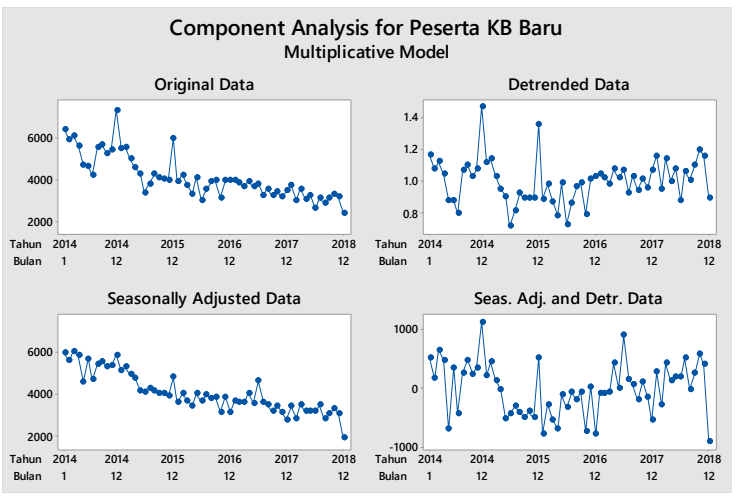

Figure 2. Trend Component Analysis Number of New Family Planning Participants in Surabaya City

Based on Figure 2, the data analysis shows four graphs including original data which shows the original data of the number of new Family Planning Program participants in Surabaya. It can be seen in the figure that the trend of the total number of new Family Planning Program participants every year experiences a downward trend. Whereas detrended data shows trends that are removed from time series. So that when viewed in a graph, showing a pattern of data that is stationary or is at a constant value consistently every time.

Seasonally adjusted data shows an adjustment graph based on seasonal components. So that the data patterns displayed are seasonal data patterns, seasonal data patterns have seasonal patterns that repeat each period. Figure 2 illustrates the pattern of seasonal data on the number of new Family Planning Program participants recurred in the 12th month. Whereas seasonally adjusted and detrended data show a combined graph of seasonal components and non-trend data. The figure shows that there was an increase in the 6th month period.

\section{Seasonal Component Analysis}

Based on the results of data analysis, seasonal component analysis is obtained on Figure 3. Based on Figure 3, there is an analysis of the seasonal component of the number of new Family Planning participants, where the average seasonal index from months 1-12 are shown in table 2 .

The seasonal component analysis in table 2 shows that the seasonal component indicates the number of new Family Planning Program participants having an expected value of $100 \%$. The result in the twelfth month has the highest seasonal pattern of $123 \%$, has a value of $23 \%$ higher than the expected seasonal index, while in the sixth month it is the lowest seasonal index of $81 \%, 19 \%$ smaller than the expected seasonal index.

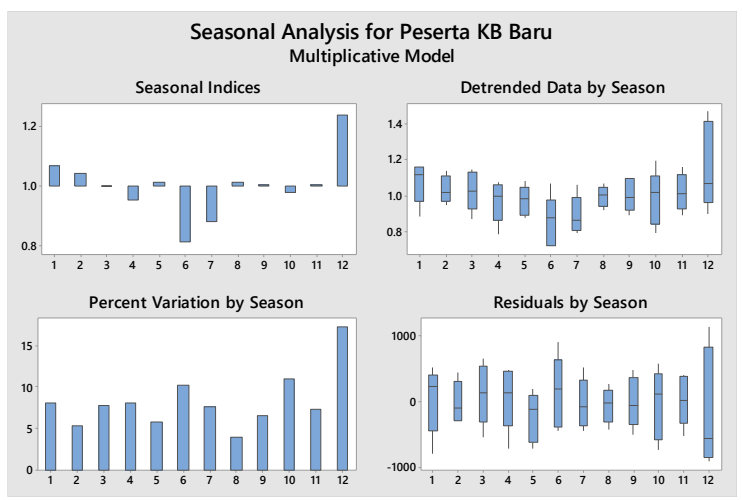

Figure 3. Seasonal Component Analysis Number of New Family Planning Program Participants in Surabaya

Table 2. Seasonal Index Average

\begin{tabular}{cc}
\hline $\begin{array}{c}\text { The ....... } \\
\text { month- }\end{array}$ & Seasonal Index Average \\
\hline 1 & $1.06719=106 \%$ \\
2 & $1.04327=104 \%$ \\
3 & $0.99969=99 \%$ \\
4 & $0.95237=95 \%$ \\
5 & $1.01296=101 \%$ \\
6 & $0.81004=81 \%$ \\
7 & $0.87962=87 \%$ \\
8 & $1.01184=101 \%$ \\
9 & $1.00328=100 \%$ \\
10 & $0.97911=97 \%$ \\
11 & $1.00471=100 \%$ \\
12 & $1.23595=123 \%$ \\
\hline
\end{tabular}

\section{Component Cycle Analysis}

The cycle component is a wave or wave fluctuation that experiences ups and downs but is around a trend. Modeling the cycle component is difficult to do. This component has unstable data patterns or tends to go up or down.

\section{Irregular Component Analysis}

An irregular component is a component that tends to change or vary in time series data after eliminating the rest of the analysis. An 
irregular component is usually called error or residual. The results of forecasting the number of new Family Planning Program participants in the city of Surabaya in 2019 are shown in table 3.

Table 3. Forecasting Results Number of New Family Planning Program Participants in Surabaya City in 2019

\begin{tabular}{ll}
\hline \multicolumn{1}{c}{ Month } & Forecasting Results \\
\hline January & $2,776.37=2,776$ \\
February & $2,663.91=2,663$ \\
March & $2,504.53=2,504$ \\
April & $2,340.13=2,340$ \\
May & $2,440.23=2,440$ \\
June & $1,912.41=1,912$ \\
July & $2,034.33=2,034$ \\
August & $2,291.42=2,291$ \\
September & $2,223.63=2,223$ \\
October & $2,123.04=2,123$ \\
November & $2,130.16=2,130$ \\
December & $2,560.94=2,560$ \\
\hline
\end{tabular}

Table 3 shows that the results of forecasting analysis using the decomposition method, the data plot of the number of new Family Planning Program participants after forecasting is shown in figure 4 .

Figure 4 shows the forecasting results for the number of new Family Planning Program participants in 2019. The graph shows that there was a significant increase in January, August, and December 2019 and experienced a significant decrease in June 2019. The graph above shows that the initial data pattern with forecasting data tends to be the same.

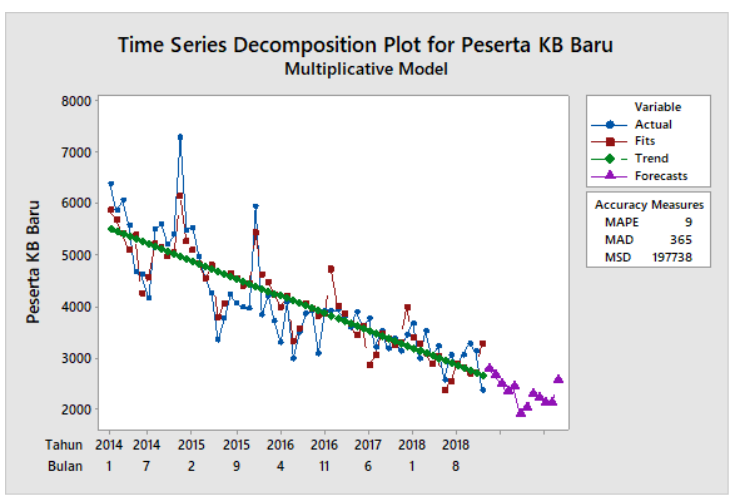

Figure 4. Time Series Decomposition Plot Data on the Number of New Family Planning Program Participants in Surabaya City

\section{Validation of Forecasting Data}

Based on the above forecasting results, the actual data (Xi) and forecast data (Fi) are shown in Table 4. Table 4 shows that the distance between actual data and forecast data varies. Month periods that have high seasonal characteristics are February and December, while those that have low seasonal characteristics are April and October.

\section{Model Conformity Test}

Based on forecasting results, we obtained forecasting observations for $\mathrm{n}=12$ time periods. Therefore, there are 12 errors/errors and produce an MSE value of 2.1675.

Table 4. Data Validation Forecasting Results Number of New Family Planning Participants in Surabaya from January-December 2019

\begin{tabular}{lcccc}
\hline \multicolumn{1}{c}{ Month } & Actual (Xi) & Forecast (Fi) & $\begin{array}{c}\text { Error / Error } \\
\boldsymbol{e} \mathbf{i}=\mathbf{X i} \mathbf{~} \mathbf{~ F i}\end{array}$ & $\boldsymbol{e 2 i}$ \\
\hline January & 2,776 & $2,776,37$ & -0.37 & 0.1369 \\
February & 2,663 & $2,663.91$ & -0.91 & 0.8281 \\
March & 2,504 & $2,504,53$ & -0.53 & 0.3136 \\
April & 2,340 & $2,340.13$ & $-0,13$ & 0.0169 \\
May & 2,440 & $2,440.23$ & -0.23 & 0.0529 \\
June & 1,912 & $1,912.41$ & -0.41 & 0.1681 \\
July & 2,034 & $2,034.33$ & -0.33 & 0.1089 \\
August & 2,291 & $2,291.42$ & -0.42 & 0.1764 \\
September & 2,223 & $2,223.63$ & -0.63 & 0.3969 \\
October & 2.123 & $2,123,04$ & -0.04 & 0.0016 \\
November & 2,130 & $2,130,16$ & $-0,16$ & 0.0256 \\
December & 2,560 & $2,560.94$ & -0.94 & 0.8836 \\
\hline Amount & $\mathbf{2 7 , 9 9 6}$ & $\mathbf{2 8 , 0 0 1 , 1}$ & $\mathbf{- 5 . 1}$ & $\mathbf{3 . 1 0 9 5}$ \\
\hline
\end{tabular}


Based on the results of forecasting analysis using software, it shows MAPE results of 9, MAD of 365, and MSD 197,738. MSE value obtained is 2.1675 which means it is smaller than the MAPE value, then MSE is the best model in time series analysis.

\section{DISCUSSION}

Time series has several methods, one of which is a decomposition method. The steps in the decomposition method are to divide the data into four main components, namely analysis of trend, seasonal, cycle, and irregular components (Yuni, Talakua and Lesnussa, 2015). Then forecasting of the new Family Planning Program participants' data and then looking for the best model by looking at the smallest error value. Forecasting analysis can be used as a means for the government to formulate plans to make policies related to family planning programs.

The decomposition method generally has the following equation:

Where:

$$
X_{t}=f\left(I_{t} \cdot T_{t} \cdot C_{t} \cdot E_{t}\right)
$$

$X_{t}=$ actual data

$I_{t}=$ seasonal index

$C_{t}=$ cycle element

$E_{t}=$ error / error

\section{Trend Component Analysis}

Trend data patterns can be seen from the increase and decrease in time series over a certain period. The ratio-trend decomposition method in the multiplicative model has the equation viz

$$
X_{t}=f\left(I_{t} * T_{t} * C_{t}\right) * E_{t}
$$

The trend data pattern in this study produces a trend that decreases every year, but the monthly data experiences an up and downtrend so that the trend of this data monthly tends to be unstable.

\section{Seasonal Component Analysis}

Seasonal data patterns can be seen if data influenced by seasonal factors that show significant numbers, so the data can show patterns that go up and down from one period to the next. The process of calculating the seasonal index begins with calculating moving averages. The next step of the data is divided by the appropriate moving averages. The results of the next division are calculated using the median average for each period. The median average is then added or multiplied by the correction factor so that the overall average becomes 1 for the multiplicative decomposition model (Muhammad and Kharis, 2014). The last result is called the seasonal index.

In this study only shows the final result, which is a seasonal index, because it uses computer software. The seasonal index results in this study are the twelfth period is the highest seasonal index and the sixth period is the lowest seasonal index.

\section{Irregular Component Analysis}

Irregular component or commonly called error/error/residue is a component that is considered to exist, although it cannot be predicted, but can be identified (Muhammad and Kharis, 2014). In this study, the irregular component is only used to find error values in new Family Planning participant data.

\section{Model Conformity Test}

The best forecasting model has a good accuracy level. In measuring accurate data, there are several measuring tools used, namely Mean Square Error (MSE), Mean Absolute Error (MAE), and Mean Absolute Percentage Error (MAPE) (Aprilia, 2018). If the results of the study have several measuring instruments as above, then the error value chosen is the smallest error.

In this study, the resulting error values are MAPE of 9, MAD of 365, and MSD 197,738. While the MSE value after the calculation is 2.1675 which means it has a value less than the MAPE value, then MSE is the best model in time series analysis.

\section{Forecasting Results}

The Family Planning Program has a purpose in controlling population growth by reducing birth rates. The Family Planning Program was quite successful in reducing the rate of population growth in 1971-1980 to 20002010 from $2.31 \%$ to $1.49 \%$. The success of this program has an impact on reducing birth and death rates so that it can open opportunities for population development to improve the quality of human resources from various aspects, such as economics, health, and education (Hafsari, 
2018). However, based on data from the Surabaya PCWECP, new Family Planning Program participants from 2014 to 2018 experienced an increase and decrease each month, but based on the overall amount in the year experienced a significant decrease. Data patterns can be seen in Figure 1.

Based on research done by Arianti and Wibowo (2015) regarding forecasting the number of new IUD Family Planning participant achievements in Jombang, the results of forecasting decreased in 2015 and 2016. Unlike Pratama and Indriani (2017) research, the results of forecasting new IUD Family Planning Program participants in East Java increased by $0.28 \%$ from 2016.

This research resulted in forecasting new Family Planning Program participants with the decomposition method in January 2019 as many as 2776 participants and in December 2019 as many as 2,560 participants. The result of MSE value is 2.1675 . From the forecasting results, it can be concluded that the number of new Family Planning Program participants in Surabaya has decreased.

Based on several studies and research results that have been presented, it can be concluded that the number of new Family Planning Program participants can increase or decrease every year. Several factors might influence people not to apply family planning including lack of knowledge, lack of experience resulting in fear, past beliefs, difficult procedures, and other environmental influences (Arianti and Wibowo, 2015). Another factor that can influence people not to use contraceptives is the lack of contraceptive supplies, such as in Malinau (district), the availability of contraceptives is constrained due to the lack of distribution from the central government to Malinau (Bawing, Wilopo, and Padmawati, 2017).

Based on Herawati (2014), even though the knowledge about family planning programs is good, some factors can cause low usage of contraception, which is the unaffordable price especially for implantable contraception. The impact or effect caused after the use of contraceptives is also one of the factors in the low number of family planning participants. Side effects that are often complained of is a change in menstrual patterns and weight gain.

Forecasting methods can help the authorities to anticipate and determine policies regarding Family Planning Programs and the use of contraceptives (Pratama and Indriani, 2017). The results of forecasting that have been made can be taken into consideration for determining the policy to increase the participation of family planning participants.

Efforts that can be made to increase the use of any type of contraception is to change the strategy during the acceptor taxation process. According to research (Januar, 2011), Family Planning Program activity policies can be implemented well if during the communication process between the authorities and the acceptors is carried out according to the stated objectives. The intended communication can be through clarity when delivering information. Besides, family planning program stakeholders must also be empowered, such as conducting routine training or training so that their knowledge and abilities increase. According to Azis (2012) the success of the program can be achieved by providing a consumer complaint service to facilitate the family planning service process and can help adjust the desires of acceptors related to the Family Planning Program.

According to research conducted by Pratama and Indriani (2017), other efforts that can be done are making policies regarding the installation of contraceptives free or not paid for underprivileged families and distributing contraceptives in each region equally.

Forecasting results that have been carried out in this study are only used as a minimum standard for the number of new Family Planning Program participants in Surabaya in 2019. Data from this study can be used by other researchers for forecasting in the coming year or other research related to Family Planning Program.

\section{CONCLUSIONS AND SUGGESTIONS}

\section{Conclusion}

Trend equation model obtained from forecasting the number of new Family Planning Program participants with the decomposition method viz $\mathrm{Yt}=5538-48.14 X_{t}$. The new Family Planning Program participants data has a declining trend from 2014-2018.

The results of forecasting the number of new family planning participants from January to December 2019 were 2,776, 2,663, 2,504, 2,340, 2,440, 1,912, 2,034, 2,291, 2,223, 2,123, 2,130 and 2,560 participants. 
The error value generated by this research is MAPE of 9, MAD of 365, MSD 197,738, and MSE of 2.1675.MSE is the smallest error value, so it becomes the best model in this study.

\section{Suggestion}

For the Surabaya City PCWECP institution, the East Java Province National Family Planning Coordinating Board, as well as the authorities, can improve good communication to prospective acceptors. Furthermore, the agency can improve the ability of family planning program stakeholders by conducting routine training and increasing the number of IEC activities (Communication, Information, and Education) in the targeted areas.

For further researchers, forecasting can be done by applying the decomposition method with more various data. The decomposition method is the oldest, but the forecasting results produced are still accurate.

\section{REFERENCES}

Aprilia, D., 2018. Penerapan Metode Forecast Exponential Smoothing pada Jumlah Pasien Puskesmas. Jurnal Biometrika dan Kependudukan, 5 (2), pp.146-156.

Arianti, C., and Wibowo, A., 2015. Pemodelan ARIMA Jumlah Pencapaian Peserta KB Baru IUD. Jurnal Biometrika dan Kependudukan, 4 (2), pp.191-200.

Azis, S., 2012. Management of Family Planning Programs. Media of Health Research and Development, 7 (03 \& 04 Dec).

Bawing, P., Wilopo, S. A., and Padmawati, R.S., 2017. Analisis Pelaksanaan Kebijakan Program Keluarga Berencana: Studi Kasus di Malinau. BKM Journal of Community Medicine and Public Health, 33 (12) pp.615-622.

Hafsari, T. A., 2018. Meraih Bonus Demografi melalui Program Keluarga Berencana. [online] Available at: <http://kependudukan.lipi.go.id/en/populat ion-study/population-dynamics/474meraih-bonus-demografi-melaluiprogram-keluarga-berencana> [Accessed 18 Jun. 2019].

Harjono, A. E., and Kuntoro, 2017.
Perbandingan Hasil Peramalan Jumlah Kasus HIV Berdasarkan Jenis Kelamin di Kota Malang dengan Metode Exponential Smoothing. Jurnal Biometrika dan Kependudukan, 6 (1), pp. 9-16.

Herawati, R., 2014. Faktor-Faktor yang Mempengaruhi Rendahnya Pemakaian KB Implan di Desa Margamulya Wilayah Kerja Puskesmas Rambah Samo I Tahun 2013. Maternity and Neonatal, 1 (3), pp.196-209.

Hyndman, R. J., and Athanasopoulos, G., 2018. Forecasting: Principles and Practice. 2nd ed. Melbourne: OTexts.

Januar, I., 2011. Implementation of Family Planning Program (KB) Policy in the City of Bandung. (July).

Kasanah, L. N., 2016. Aplikasi Autoregressive Integrated Moving Average (ARIMA) untuk Meramalkan Jumlah Demam Berdarah Dengue (DBD) di Puskesmas Mulyorejo. Jurnal Biometrika dan Kependudukan, 5 (2), pp.177-186.

Makridakis, S., Wheelwright, S.C., and McGee, V.E., 1995. Metode dan Aplikasi Peramalan. Revised Edition. 2nd ed. Jakarta: Erlangga.

Muhammad, N., and Kharis, A., 2014. Analisis Peramalan Pendaftaran Siswa Baru Menggunakan Metode Seasonal ARIMA dan Metode Dekomposisi. Thesis. Universitas Islam Negeri Syarif Hidayatullah.

National Board of Population and Family Planning, 2018. Peran BKKBN di Balik Gerakan Penanggulangan Stunting. Jurnal Keluarga, (1), pp.44.

Pratama, Y. A., and Indriani, D., 2017. Peramalan KB Baru IUD dengan Metode Automatic Clustering and Fuzzy Logical Relationship. Jurnal Biometrika dan Kependudukan, 6 (2), pp.144-153.

Law of Indonesian Republic Number 52 Year 2009 Conserning Perkembangan Kependudukan dan Pembangunan Keluarga.

Yuni, S., Talakua, M. W., and Lesnussa, Y. E. S., 2015. Peramalan Jumlah Pengunjung Perpustakaan Universitas Pattimura Ambon Menggunakan Metode Dekomposisi. Barekeng: Jurnal Ilmu Matematika dan Terapam, 9 (1), pp.41-50. 